DOI https://doi.org/10.15589/znp2019.3(477).10

УДК 502.55

\title{
A NEW APPROACH TO SHIP BILGE WATERS CLEANING
}

\section{НОВИЙ ПІДХІД ДО ОЧИЩЕННЯ СУДНОВИХ ЛЛЯЛЬНИХ ВОД}

\author{
Natalia P. Bykovets \\ bnp.di2017@gmail.com \\ ORCID: 0000-0002-6365-4701
}

\author{
Н. П. Биковець, \\ канд. техн. наук
}

\author{
Danube Institute of the National University “Odessa Maritime Academy”, Izmail \\ Дунайський інститут Національного університету «Одеська морська академія», м. Ізмаїл
}

\begin{abstract}
In accordance with the requirements of the main international document MARPOL-73/78, measures should be taken to reduce and prevent pollution of the marine environment. According to the above mentioned document, it is prohibited to discharge harmful substances that are transported by ships. During the operation of the vessel, bilge waters are formed. These are complex waters containing oil products of various kinds, mechanical impurities of organic and inorganic origin. Depending on the tonnage, type and age of the vessel, the technical condition of the equipment, different amounts of bilge waters are formed. These waters need purification. This article deals with ship bilge waters cleaning methods. The most common cleaning methods are considered. The advantages and disadvantages of these methods are indicated. The analysis of the published works show, that the mechanical methods of cleaning allow only to conduct the previous stage of cleaning. Physicochemical, chemical, biological or combined methods should be applied for the deeper cleaning. The methods of the physicochemical cleaning of bilge waters are most widespread. They contain superficially active substances, which cause formation of stable emulsions that is difficult to divide. Formed emulsion is the result in the decrease of efficiency of cleaning process.

The principle of operation of vacuum evaporation units is considered. Their work is based on the physical principle of boiling and condensation of liquid vapors. The process of vacuum evaporation makes it possible to separate nonvolatile compounds. Vacuum evaporation units allow efficient solution of water treatment problems in various industries. They are economical and small in size. Applying of these units leads to reducing of energy consumption by up to $75 \%$. The article proposes a method of treating bilge water by evaporation. Using of vacuum evaporators in technology of bilge water cleaning, their operating principles must be slightly modified. The presented method of processing bilge water will destroy the stable emulsions under the influence of temperature. The result of described method is the formation of dehydrated emulsion and distilled water. If necessary, the distilled water can be reused. We also get environmental and economic benefits. Waste management costs can be reduced by up to $90 \%$.
\end{abstract}

Key words: bilge water; cleaning methods; vacuum evaporation unit; evaporation.

Анотація. У зв'язку з вимогами головного міжнародного документа МАРПОЛ-73/78 необхідно передбачати заходи зі скорочення та відвертання забруднення морського середовища. Згідно із зазначеним документом, забороняється скидання шкідливих речовин, які перевозять на судах. На судні у процесі його експлуатації утворюються лляльні води. Це складні води, які містять нафтопродукти різних видів, механічні домішки органічного та неорганічного походження. Залежно від водотоннажності, типу та віку судна, технічного стану устаткування утворюється різна кількість лляльних вод. Ці води потребують очищення. У статті висвітлені питання, пов'язані з використанням різних методів очистки суднових лляльних вод. Розглянуті найбільш поширені методи очищення. Вказані переваги та недоліки даних методів. 3 аналізу опублікованих робіт встановлено, що механічні методи очистки дозволяють провести лише попередній етап очистки. Для більш глибокої очистки необхідно застосовувати фізико-хімічні, хімічні, біологічні або комбіновані методи. Визначено, що найбільш поширені методи фізико-хімічного очищення лляльних вод. До складу лляльних вод входять поверхнево-активні речовини, які призводять до утворення стійких емульсій, що важко розділити. Утворена емульсія призводить до зниження ефективності процесу очистки.

Розглянуто принцип дії установок вакуумного випарювання. Їхня робота базується на фізичному принципі кипіння та конденсації парів рідин. Процес вакуумного випарювання дає можливість відділення нелетких з'єднань. Установки вакуумного випарювання дозволяють ефективно вирішувати проблеми водоочистки в різних галузях промисловості. Вони є економічними та малогабаритними. Використання установок даного типу призводить до зниження енерговитрат до 75\%. У статті пропонується метод обробки лляльних вод за допомогою випарювання. Для застосування установки вакуумного випарювання в технології очищення суднових лляльних вод до принципової схеми діючого обладнання внесені незначні зміни. Представлений метод обробки лляльних вод дозволить зруйнувати стійкі емульсії під впливом температури. У результаті даного методу обробки утворюється зневоднена емульсія та дистильована вода, яку, за потреби, можна використати вдруге. Також отримуємо екологічні й економічні переваги. Зниження витрат на утилізацію відходів можливе аж до $90 \%$.

Ключові слова: лляльні води; методи очистки; вакуумна випарна установка; випарювання. 


\section{ТЕХНОЛОГІЇ ЗАХИСТУ НАВКОЛИШНЬОГО СЕРЕДОВИЩА № 3- 2019}

\section{ПОСТАНОВКА ЗАДАЧІ}

Серед існуючих та відомих сьогодні методів очистки суднових вод, що у своєму складі містять нафтопродукти, можна виділити такі [1]:

- механічні методи (відстоювання);

- фізико-хімічні методи (флотація, адсорбція);

- хімічні методи (озонування);

- біологічні методи (використання мікроорганізмів).

3 погляду глибини очищення (тобто величини остаточної концентрації нафтопродуктів в очищеній воді) їх можна розділити на методи грубої (попередньої) та глибокої очистки (доочищення).

Перелічені методи давали добрі результати під час експериментальних досліджень, які проводили в лабораторних умовах. Однак під час роботи в суворих кліматичних умовах відкритого моря в більшості систем спостерігалось відчутне зниження їхньої ефективності. Принцип роботи систем очистки в основному базується на використанні гравітаційної сили, дія якої може бути подолана за коливань судна навіть під час помірного хвилювання. У результаті знижується якість обробки. У свою чергу, не можна не враховувати й різкі перепади концентрації нафтопродуктів, які також призводять до проблем у системах очищення лляльних вод.

\section{АНАЛІЗ ОСТАННІХ ДОСЛІДЖЕНЬ І ПУБЛІКАЦІЙ}

Зниження концентрації нафтопродуктів у воді може відбуватися в результаті їх природного розпаду та хімічного окислення, випаровування та біологічної деструкції мікрофлорою [2]. Але в умовах навколишнього середовища ці процеси відбуваються нешвидко. У зв'язку із цим для інтенсифікації процесів очищення води від нафтопродуктів використовують механічні, хімічні, фізико-хімічні та біологічні методи, а також їх комбіновані схеми, які дозволяють досягти необхідного ступеня очистки з мінімальними затратами [3]. Необхідно зазначити, що вибір способу очистки визначається джерелом та характером забруднення $[4 ; 5]$.

Механічна обробка $є$ попереднім етапом очистки. Вона дозволяє усунути з основної маси крупнодисперсні фракції. Механічні способи малоефективні, оскільки забезпечують видалення вуглеводневих компонентів лише $з$ поверхневого органічного шару.

Для осадження нафтопродуктів у вигляді нерозчинних неутилізованих осадів використовують хімічні методи, які базуються на внесенні в забруднену воду дорогих хімічних реагентів (коагулянтів і флокулянтів), які, у свою чергу, можуть стати причиною вторинного забруднення води, яку очищують.

Для видалення із лляльних вод колоїдних і мілкодисперсних домішок, а також важких металів, фенолів, кислот, лугів застосовують фізико-хімічні методи. Серед них найбільш уживаних методи адсорбції нафтопродуктів на поверхні сорбентів [2; 6]. Перевагами сорбційних методів $\epsilon$ їхня сумісність 3 іншими способами збору нафтопродуктів і можливість багаторазового використання сорбенту після регенерації. Як сорбенти використовують як природні (торф, активоване вугілля, тирса, перліт, глина), так і штучні (пінополіуретан, кераміка, синтетичні волокна) пористі матеріали. Під час вибору матеріалів необхідно враховувати їхню екологічність і доступність у заданому регіоні [2].

Біологічні методи очистки передбачають використання вуглеводнеокислюючих мікроорганізмів, які здатні засвоювати різні вуглеводи нафти як єдине джерело вуглецю [7; 8]. Перевагами біологічних методів є їхея ефективність, економічність, екологічна безпечність та відсутність вторинних забруднень.

Усі відомі методи, у яких використовують густинну стратифікацію та механічний розподіл, характеризуються невисокою якістю очищення суднових лляльних вод і можуть застосовуватися лише на стадії попередньої сепарації. 3 іншого боку, методи, які на виході дають значення величини концентрації нафтопродуктів менше ніж 15 мл/г, характеризуються одним загальним недоліком - складністю своєї технічної реалізації та великими витратами (економічними, матеріальними) на поточне обслуговування [9].

Із практики очищення води, що містить нафтопродукти, адсорбція являється одним із методів, за допомогою якого можливе очищення до мінімальних остаточних концентрацій нафтопродуктів, які мають різну дисперсність у воді. Дуже широко в судновому очисному обладнанні як сорбенти для фільтрів другої (або третьої) стадії обробки використовують активоване вугілля різних марок. Але, у зв'язку з тим, що процес виготовлення активованого вугілля надто складний і тривалий, а також потребує значних витрат енергії, це в сукупності підвищує вартість даного матеріалу. Ці обставини примушують до пошуку нових, дешевших сорбентів [1].

Одним із найбільш поширених методів фізико-хімічного очищення лляльних вод $є$ флотація. Ї̈̈ використовують для видалення із забрудненої води дрібнодисперсних зважених часток, які мимовільно погано відстоюються, мінеральних і органічних речовин. Необхідна умова для здійснення повної флотації така: розмір краплі нафти має бути достатньо великим для забезпечення відносно високої частоти поверхневого контакту бульбашок газу та крапель нафти. Під час процесу в рідину, яку необхідно очистити, подається повітря, маленькі бульбашки якого, піднімаючись на поверхню води, захоплюють часточки забруднювача, утворюючи водночас насичений піноподібний шар. Перевагами флотації є безперервність процесу, широкий діапазон використання, невеликі капітальні й експлуатаційні витрати, нескладність апаратурного оформлення, високий ступінь очистки, можливість 
рекуперації речовин, які видалили. Флотація супроводжується аерацією лляльних вод, зниженням концентрації поверхнево-активних речовин (далі - ПАР), мікроорганізмів. Усі зазначені переваги сприяють подальшому проведенню наступних стадій очищення $[10 ; 11]$.

Аналіз наявних методів очищення лляльних вод доводить, що залишається актуальним питання пошуку нових, більш ефективних за капітальними й експлуатаційними витратами методів очищення.

Мета дослідження - обгрунтування використання установки вакуумного випарювання для очищення суднових лляльних вод.

\section{ОСНОВНИЙ МАТЕРІАЛ}

Відповідно до головного міжнародного документа МАРПОЛ-73/78 [12], який передбачає заходи зі скорочення та відвертання забруднення морського середовища, забороняється скидання шкідливих речовин, що перевозяться на судах або утворюються у процесі експлуатації судна. Цей документ постійно уточнюється та доповнюється відповідно до практичних потреб і нових організаційно-технічних можливостей. У шести додатках до МАРПОЛ-73/78 містяться правила, що охоплюють різні джерела забруднення із судів. У кожному додатку МАРПОЛ-73/78 відображені умови скидання в море шкідливих речовин і перелік природоохоронного устаткування, яке має бути обов'язково встановлене на судні.

У даній роботі основний акцент робиться на вимогах, відображених у Додатку I: Правила відвертання забруднення нафтою із судів. Наведений Додаток встановлює правила відвертання забруднення не лише нафтою як такою, але й водами, до складу яких входять нафтопродукти. Як відомо, нафтова плівка, що утворюється на поверхні води, перешкоджає обміну теплотою й водяними парами між гідросферою й атмосферою. Крім того, нафта токсична і призводить до загибелі планктону й інших морських організмів.

На судні у процесі експлуатації суднових механізмів утворюються лляльні води. Порівняно з баластними водами вони характеризуються складнішим складом через наявність у них нафтопродуктів різних видів, механічних домішок органічного й неорганічного походження. Залежно від типу, водотоннажності та віку судна, потужності енергетичної установки, від технічного стану устаткування і від дотримання правил його експлуатації утворюється різна кількість лляльних вод. Головними причинами утворення лляльних вод $є$ :

- протікання палива, мастила, забортної та прісної води із трубопроводів, теплообмінних апаратів, насосів;

- протікання нафтопродуктів під час ремонту механізмів, паливної та масляної систем;

- аварійні протікання.
Лляльні води також утворюються під час промивання деталей машин, пропарювання паливних і масляних цистерн.

У середньому вміст нафтопродуктів у лляльних водах становить не менше 2000 млн $^{-1}$ (2 000 ppm). Нині, згідно з вимогами Конвенції МАРПОЛ-73/78, вміст нафтопродуктів в очищених лляльних водах, що скидаються із судів, не повинен перевищувати 15 млн $^{-1}$ (15 ppm).

Відповідно до Додатка I, забороняється будь-яке скидання в морі нафти або суміші, у складі якої є нафта, за винятком випадків, коли судно перебуває поза межами особливого району. Для Додатка I особливими районами є: Середземне море, Балтійське море, Чорне море, Червоне море, район заток (Персидська й Оманська затоки), Аденська затока і район Антарктики на південь від $60^{\circ}$ південної широти, води Північно-Західної Європи, район Омана Аравійського моря та південні води Південної Африки. Також зазначимо, що для кожного додатка МАРПОЛ-73/78 встановлені свої «особливі райони» [12].

Із часом світова спільнота приходить до рішення про ще менш допустимі концентрації нафтопродуктів у воді, що скидається в море. Обмеження, що вводяться, планують довести до 5 pрm та повної заборони процесу скидання в життєво важливі водойми.

Для здійснення контролю використовують різні методи, які включають як повітряні, так і космічні засоби визначення фактів розливу вуглеводнів у Світовому океані. 3 метою відвертання забруднення водного середовища нафтопродуктами всі судна мають бути оснащені системами очищення лляльних вод, причому встановлене устаткування має бути протестоване та відповідати вимогам резолюції MERC.107 (49) [13]. Отже, процес очищення лляльної води механічним, хімічним, фізико-хімічним або біологічним способом припускає її трифазне розділення, третьою фазою є шлам.

За такої безлічі способів очищення постає питання, чому згадані системи або комплекси не повною мірою можуть забезпечити якість роботи в реальних умовах. Один із варіантів відповіді криється у складі лляльних вод. До їхнього складу, окрім води, палива, мастильної олії, олії для гідравлічних систем, входять миючі й інші препарати. У процесі виконання ремонтних і сервісних робіт використовуються миючі засоби, створені на основі ПАР. Наявність у лляльних водах ПАР призводить до утворення стійких емульсій, які важко розділити. Емульсія являє собою суміш нафтопродуктів і води, яка рівномірно розподіляється по всьому об'єму води та призводить до зниження ефективності процесу сепарації [14]. До того ж накладається ще дія коливань судна та різна за величиною концентрація нафтопродуктів у лляльних водах.

Нині стають популярними установки вакуумного випарювання, робота яких базується на фізично- 


\section{ТЕХНОЛОГІЇ ЗАХИСТУ НАВКОЛИШНЬОГО СЕРЕДОВИЩА № 3. 2019}

му принципі кипіння та конденсації парів рідин, які піддаються обробці [15]. Шляхом переходу з рідкого стану в газоподібний досягається значна економія енергії та підвищується ефективність роботи системи. Цей перехід відбувається в умовах вакууму за температури, нижчої, ніж температура кипіння за атмосферного тиску. За допомогою вакуумного випарювання з'являється можливість відділення нелетких 3'єднань, наявних у розчині. На виході, з одного боку, отримують демінералізовану воду, 3 іншого боку більш концентрований кінцевий продукт, який у 10 60 разів менше початкового об'єму стоків і містить усі забруднюючі речовини. Важливою характеристикою цих установок $є$ їхня здатність значно зменшувати об'єми відходів переробки, що приводить, у свою чергу, до зменшення витрат на їх утилізацію.

Сучасні вакуумні випарні установки (далі - ВВУ) - економічні, малогабаритні установки, що дозволяють ефективно вирішувати проблеми водоочистки в різних галузях промисловості [16].

Принцип дії даних установок базується на фізичних закономірностях, пов'язаних із відмінністю температур кипіння різних розчинів. Вода, досягнувши температури кипіння, випаровується, звільняючись від розчинених і нерозчинених домішок. Пара піднімається вгору, а розчинені хімічні речовини, досягаючи межі розчинності, випадають в осад і можуть бути концентровані та потім видалені. Пара, що утворилася, охолоджується, конденсується та перетворюється знову на воду. Ця вода $\epsilon$ високоочищеною і може бути знову використана.

Установки функціонують із використанням вакууму. Тобто процес кипіння вже можливий за $20-35^{\circ} \mathrm{C}$, а не за $100^{\circ} \mathrm{C}$, як це відбувається в умовах нормального атмосферного тиску. Наслідком цього є різке зниження енерговитрат (більше 75\%). Наприклад, щоб випарувати 1 літр води за нормального атмосферного тиску, необхідно 600 Вт, щоби випарувати 1 літр води за допомогою ВВУ з тепловим насосом, потрібно 160 Вт, і 90 Вт у разі установки з високим ступенем енергозребереження [16].

ВВУ мають важливі здатності, а саме: очищати одночасно різні стоки; очищати стоки навіть із високою концентрацією забруднюючих речовин (що досить проблематично за використання багатьох інших методів очищення).

Стійкі водонафтові емульсії дуже складно розділити на фракції механічним способом. 3 урахуванням специфіки нафтопродуктів застосування ВВУ вже дає позитивні результати на підприємствах нафтопереробного комплексу [17]. У концентраті виходять зневоднені нафтопродукти 3 температурою кипіння вище $100{ }^{\circ} \mathrm{C}$, а в дистиляті наявні низькокиплячі вуглеводні та вода. Водночас, якщо на вході ці продукти не розділялися, то після перегонки вони стабільно розділяються за густиною. Тому їх далі можна легко розділити різними методами.

У даній роботі пропонується ВВУ для обробки лляльних вод за допомогою випарювання, що посприяє розпаду стійких емульсій під дією температури. На рисунку 1 представлена одна із принципових схем роботи ВВУ $з$ подачею гарячої води або пари, 3 теплообмінниками, оснащеними зовнішнім кожухом і внутрішнім скребком [18]. Ці установки розраховані на отримання концентратів із дуже високою густиною та призначені для випарювання продуктів, що інтенсивно утворюють накип на теплообмінниках. Автоматичний приводний скребок служить для підтримки чистоти поверхні обміну в котлі кипіння.

У роботі розглядається пропозиція щодо внесення в дану схему незначних конструкційних змін та до-

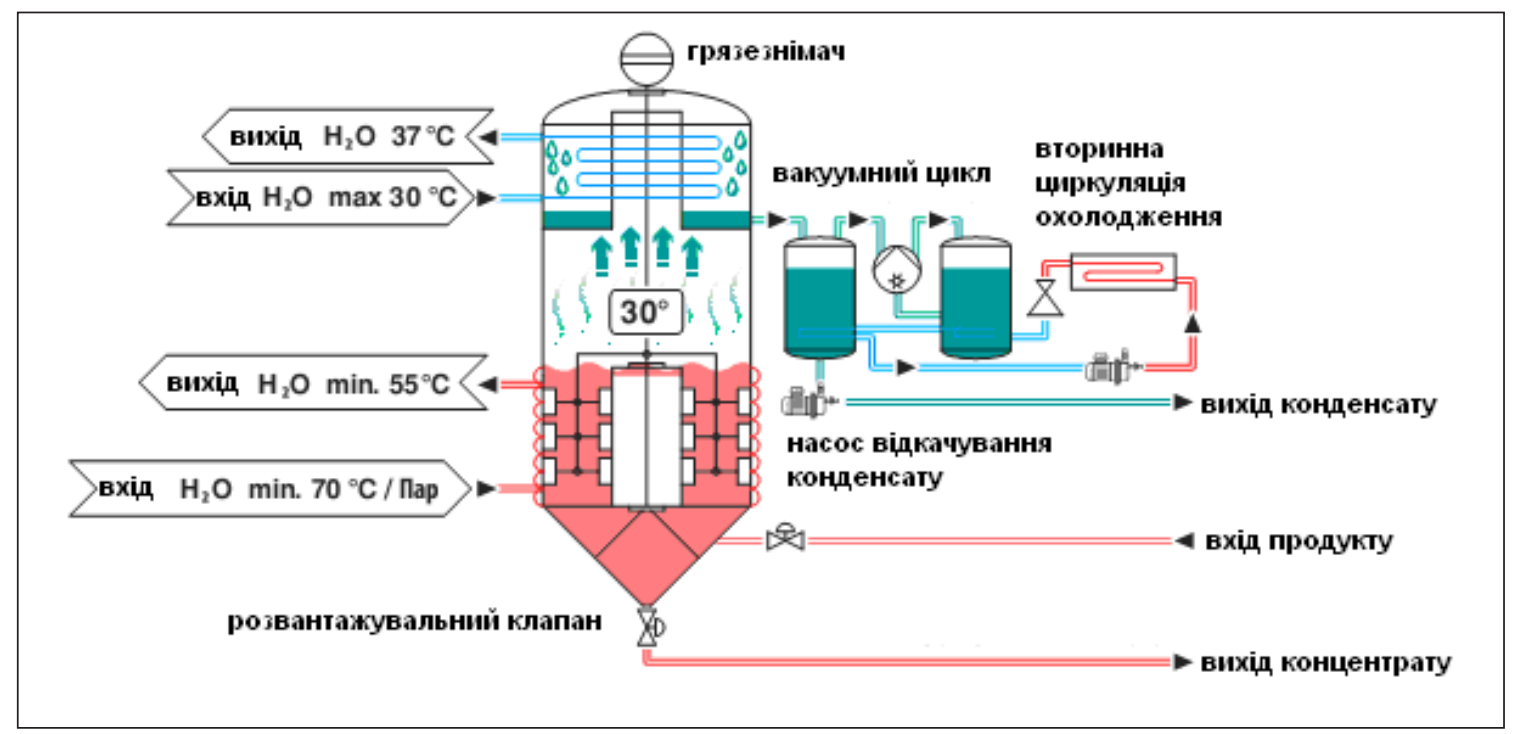

Рис. 1. Принципова схема роботи вакуумної випарної установки 


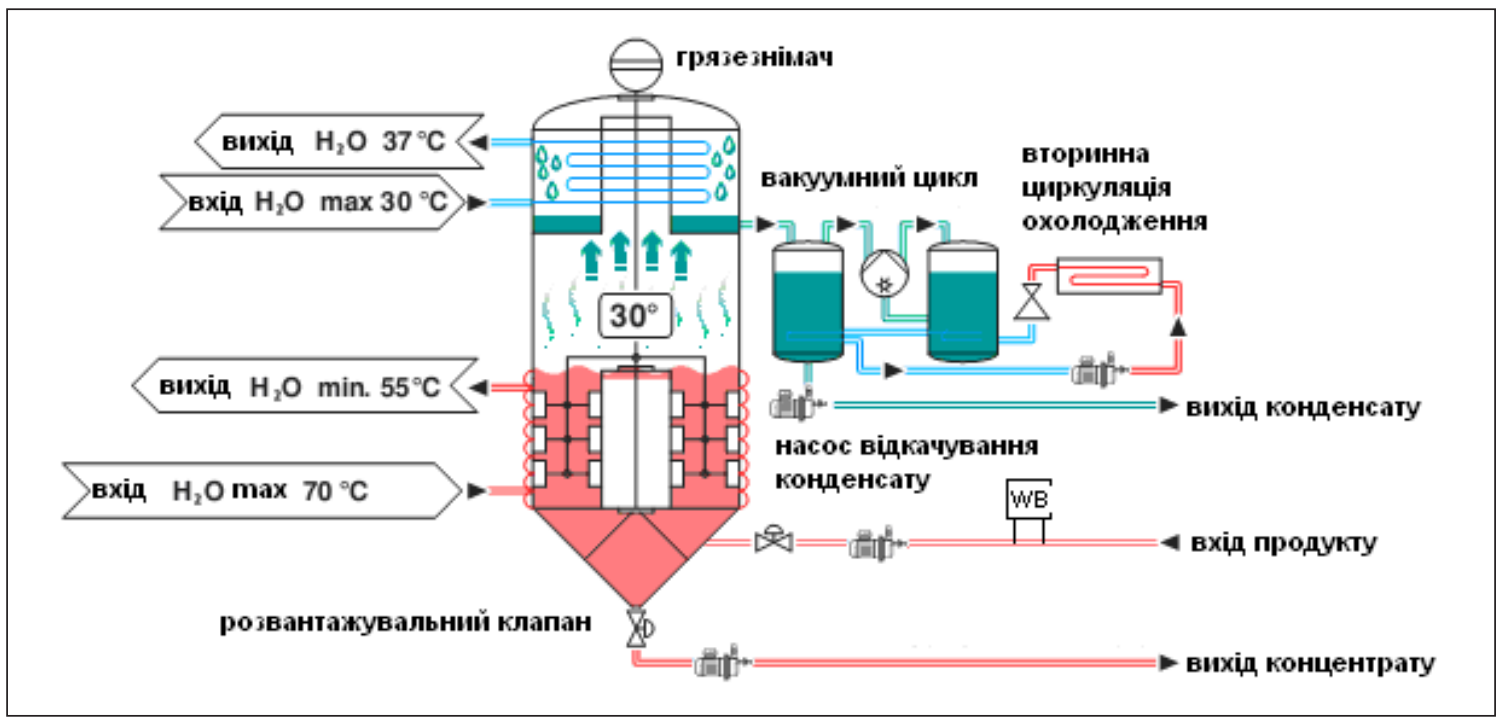

Рис. 2. Зміни у схемі роботи вакуумної випарної установки

повнень для можливого використання ВВУ з метою очищення суднових лляльних вод. Запропоновані зміни вказані на рисунку 2.

Отже, пропонується:

1) знизити температуру випарювання (температуру вхідної рідини) для відвертання випару олії разом із водою;

2) додати пристрій для здійснення контролю вступу лляльної води до установки - White Box (WB);

3) додати додаткові насоси для завантаження лляльної води та відкачування відходів.

Отже, метод обробки лляльной води за допомогою випарювання дозволить зруйнувати стійкі емульсії під впливом температури. Як видно на схемі, у випаровувач за допомогою додаткового насосу завантажують лляльную воду. Потім, знижуючи тиск, зменшують температуру кипіння рідини. Оскільки вода має найнижчу температуру кипіння з усього складу розчину, вона починає випаровуватися перша. Далі отримана пара поступає до холодильника, де конденсується та виводиться у вигляді рідини 3 котла. У результаті із лляльної води утворюється зневоднена емульсія, яку можна або перекачати на зберігання до танку, а потім здати в порту, або за допомогою інсинератора спалити.

\section{ВИСНОВКИ}

Застосування вакуумного випарювання для очищення суднових лляльних вод забезпечить значні переваги порівняно із класичними системами фізикохімічного типу або із системами біологічної обробки. Це переваги як економічні, так і екологічні. Зниження витрат на утилізацію відходів доходить аж до 90\%. Крім того, можливе повторне використання отриманої дистильованої води.

Отриману максимально очищену (майже дистильовану) воду можна скидати за борт, навіть у заборонених МАРПОЛ-73/78 районах.

Використання ВВУ на судні можливе для будьякої рідини, що, поза сумнівом, дає величезні можливості екіпажу.

Установка вакуумного випарювання не обмежена погодними умовами, оскільки працює за іншим принципом.

\section{REFERENCES}

[1] Kuchinskaya, A.A. Tehnologiya ochistki sudovyih neftesoderzhaschih vod s ispolzovaniem prirodnyih sorbiruyuschih materialov. Kand, Diss. [Technology for purification of shipboard oily waters using natural sorbent materials: Diss. Kand.]. Gosudarstvennyiy Morskoy Universitet imeni admirala F.F. Ushakova [State Maritime University named after Admiral F.F. Ushakov]. Novorossiysk, 2014. 124 p. [In Russian].

[2] Sirotkina, E.E., Novoselova, L. Yu. Materialyi dlya adsorbtsionnoy ochistki vodyi ot nefti i nefteproduktov [Materials for Adsorption Purification of Water from Petroleum and Oil Products]. Himiya v interesah ustoychivogo razvitiya [Chemistry for Sustainable Development]. 2005, V. 13, no. 3, pp. 359-375. [In Russian].

[3] Dolina, L.F. Sovremennaya tehnologiya i sooruzheniya dlya ochistki neftesoderzhaschih stochnyih vod [Modern technology and facilities for oil-contaminated wastewater treatment]. Dnepropetrovsk, Continent Publ., 2005. 296 p. [In Russian].

[4] Kuzubova, L.I., Morozov, S.V. Ochistka neftesoderzhaschih stochnyih vod: analiticheskiy obzor [Cleaning oily wastewater: Analytical Review]. Novosibirsk, 1992. 72 p. [In Russian].

[5] Lebedev, I.A., Komarova, L.F., Poletaeva, M.A., Kotsenko, E.G. Ochistka neftesoderzhaschih stochnyih vod filtrovalnosorbtsionnyimi metodami [Oil wastewater treatment by filter-sorption methods]. Polzunovskiy vestnik [Vestnik of Polzunovsky]. 2006, no. 2, pp. 380-385. [In Russian]. 


\section{ТЕХНОЛОГІЇ ЗАХИСТУ НАВКОЛИШНЬОГО СЕРЕДОВИЩА № 3- 2019}

[6] Zhukova, O.V., Morozov, N.V. Vzaimodeystvie mikroorganizmov s tverdyimi poverhnostyami - sorbentami pri snyatii lokalnogo neftyanogo zagryazneniya [The interaction of microorganisms with firm surfaces in the process of cleaning of the local oil pollution]. Vestnik TGGPU [Bulletin Tatar State University of Humanities and Education]. 2010, no. 3 (21), pp. 99-106. [In Russian].

[7] Ghazali, F.M., Rahman, R.N.Z.A., Salleh, A.B., Basri, M. [Biodegradation of hydrocarbons in soil by microbial consortium]. International Biodeterioration \& Biodegradation. 2004, V. 54, no. 1, pp. 61-67.

[8] Mikesková, H., Novotný, Č., Svobodová, K. [Interspecific interactions in mixed microbial cultures in a biodegradation perspective]. Applied Microbiology and Biotechnology. 2012, V. 95, no. 4, pp. 861-870.

[9] Tkachenko, I.V. Ochistka neftesoderzhaschih vod morskih sudov metodom gidrodinamicheskoy superkavitatsii potoka [Purification of oily waters of marine vessels by hydrodynamic supercavitation flow]. Universum: Technical science. 2018, no. 3(48). Available at: http://7universum.com/ru/tech/archive/item/5656. [In Russian].

[10] Kravets, M. N., Vasina, M. V. Effektivnost ochistki neftesoderzhaschih stochnyih vod metodom flotatsii [The effectiveness of the treatment of oily wastewater by flotation]. Molodoy uchenyiy [Young scientist]. 2017, no. 46, pp. 99-101. Available at: https://moluch.ru/archive/180/46420/. [In Russian].

[11] Bykovets, N.P., Danilyan, A. G., Kirsanova, V.V., Tiron-Vorobiova, N. B. Dekarbonizatsiya atmosferyi pri ekspluatatsii vodnogo transporta [Decarbonization of atmosphere during exploitation of water transport]. International Trends in Science and Technology: materialyi VIII mezhdunarodnoy nauchno-prakticheskoy konferentsii 25 dekabrya 2018g [International Trends in Science and Technology: Proceedings of the 7th International Scientific and Practical Conference on December 25, 2018], 2018, pp. 6-9. [in Russian].

[12] The International Convention for the Prevention of Pollution from Ships. Available at: https://ru.wikipedia.org/wiki.

[13] Resolution MEPC.107(49). Revised guide lines and specifications for pollution prevention equipment for machinery space bilges of ships. London, IMO Publ., 2003. 25 p.

[14] Ochistka lyalnoy vodyi - kakoy sposob separatsii luchshe? [Bilge water treatment - which separation method is better?]. Morskaya birzha (Sudohodstvo) [Maritime Market (Shipping)]. 2010, no 2(32). Available at: https://www.maritimemarket. ru/article.phtml?id=1189. [In Russian].

[15] Vakuumnoe vyiparivanie [Vacuum evaporation]. Available at: https://www.kovofinis.cz/ru/vakuumnyy-isparitel. [In Russian].

[16] Vakuumnoe vyiparivanie [Vacuum evaporation]. Available at: https://studbooks.net/887938/ekologiya/vakuumnoe vyparivanie. [In Russian].

[17] Ispolzovanie vakuumnogo vyiparivaniya dlya obezvozhivanie nefteproduktov [The use of vacuum evaporation for dehydration of oil products]. Available at: https://www.potram.ru/index.php?page=18. [In Russian].

[18] IWE - Industrial Water Evaporators. Available at: https://www.iwe-evaporators.com/download/Cat.\%20RU.pdf.

\section{СПИСОК ВИКОРИСТАНОЇ ЛІТЕРАТУРИ}

[1] Кучинская А. Технология очистки судовых нефтесодержащих вод с использованием природных сорбирующих материалов : дис. .... канд. тех. наук: 05.08.05. Новороссийск, 2014. 124 с.

[2] Сироткина Е., Новоселова Л. Материалы для адсорбционной очистки воды от нефти и нефтепродуктов. Химия 6 интересах устойчивого развития. 2005. № 13. С. 359-337.

[3] Долина Л. Современная технология и сооружения для очистки нефтесодержащих сточных вод. Днепропетровск : Континент, 2005. 296 с.

[4] Кузубова Л., Морозов С. Очистка нефтесодержащих сточных вод: аналитический обзор. Новосибирск, 1992.72 с.

[5] Очистка нефтесодержащих сточных вод фильтровально-сорбционными методами / И. Лебедев и др. Ползуновский вестник. 2006. № 2. С. 380-385.

[6] Жукова О., Морозов Н. Взаимодействие микроорганизмов с твердыми поверхностями - сорбентами при снятии локального нефтяного загрязнения. Вестник Татарского государственного гуманитарно-педагогического универcumema. 2010. № 3 (21). C. 99-106.

[7] Biodegradation of hydrocarbons in soil by microbial consortium / F. Ghazali et al. International Biodeterioration \& Biodegradation. 2004. Vol. 54. № 1. P. 61-67.

[8] Mikesková H., Novotný Č., Svobodová K. Interspecific interactions in mixed microbial cultures in a biodegradation perspective. Applied Microbiology and Biotechnology. 2012. Vol. 95. № 4. P. 861-870.

[9] Ткаченко И. Очистка нефтесодержащих вод морских судов методом гидродинамической суперкавитации потока. Universum : Технические науки. 2018. № 3 (48). URL: http://7universum.com/ru/tech/archive/item/5656.

[10] Кравец М., Васина М. Эффективность очистки нефтесодержащих сточных вод методом флотации. Молодой ученый. 2017. № 46. C. 99-101. URL: https://moluch.ru/archive/180/46420/.

[11] Декарбонизация атмосферы при эксплуатации водного транспорта / Н. Быковец и др. International Trends in Science and Technology : материалы VIII Международной научно-практической конференции, 25 декабря 2018 г. Польша, Варшава, 2018. Т. 2. С. 6-9.

[12] Международная конвенция по предотвращению загрязнения с судов. URL: https://ru.wikipedia.org/wiki/.

[13] Resolution MEPC.107 (49). Revised guide lines and specifications for pollution prevention equipment for machinery space bilges of ships. London : IMO, 2003. 25 p.

[14] Очистка льяльной воды - какой способ сепарации лучше? Морская биржа. 2010. № 2 (32) (Судоходство). URL: https://www.maritimemarket.ru/article.phtml?id=1189.

[15] Вакуумное выпаривание. URL: https://www.kovofinis.cz/ru/vakuumnyy-isparitel.

[16] Вакуумное выпаривание. URL: https://studbooks.net/887938/ekologiya/vakuumnoe_vyparivanie.

[17] Использование вакуумного выпаривания для обезвоживание нефтепродуктов. URL: https://www.potram.ru/index. php?page $=18$.

[18] IWE - Industrial Water Evaporators. URL: https://www.iwe-evaporators.com/download/Cat.\%20RU.pdf. 